\title{
Expression of mRNAs for Pro-and Anti-Apoptotic Factors in Granulosa Cells and Follicular Fluid of Women Undergoing in Vitro Fertilization. A Pilot Study
}

\author{
Jozsef Bodis \\ Pécsi Tudományegyetem Általános Orvostudományi Kar: Pecsi Tudomanyegyetem Altalanos Orvostudomanyi Kar \\ Endre Sulyok ( $\nabla$ esulyok@t-online.hu ) \\ Faculty of Health Sciences, University of Pécs, https://orcid.org/0000-0003-1464-6024 \\ Akos Varnagy \\ Pécsi Tudományegyetem Általános Orvostudományi Kar: Pecsi Tudomanyegyetem Altalanos Orvostudomanyi Kar \\ Viktória Prémusz \\ University of Pecs https://orcid.org/0000-0002-4059-104X \\ Krisztina Godony \\ Pecsi Tudomanyegyetem Altalanos Orvostudomanyi Kar \\ Alexandra Makai \\ Pecsi Tudomanyegyetem Egeszsegtudomany Kar \\ Agnes Szenczi \\ Pécsi Tudományegyetem Általános Orvostudományi Kar: Pecsi Tudomanyegyetem Altalanos Orvostudomanyi Kar \\ Timea Varjas \\ Pécsi Tudományegyetem Általános Orvostudományi Kar: Pecsi Tudomanyegyetem Altalanos Orvostudomanyi Kar
}

Research article

Keywords: apoptosis, follicular fluid, granulosa cell, in vitro fertilization, mRNA expression

Posted Date: March 18th, 2021

DOI: https://doi.org/10.21203/rs.3.rs-330029/v1

License: @ (i) This work is licensed under a Creative Commons Attribution 4.0 International License. Read Full License 


\section{Abstract}

Background

This observational clinical study evaluated the expression levels and predictive values of some apoptosis-related genes in granulosa cells (GCs) and follicular fluid (FF) of women undergoing in vitro fertilization (IVF).

\section{Methods}

GCs and FF were obtained at oocyte retrieval from 31 consecutive patients with heterogeneous infertility diagnosis (age: $34.3 \pm 5.8$ years, body mass index: $24.02 \pm 3.12 \mathrm{~kg} / \mathrm{m} 2$, duration of infertility: $4.2 \pm 2.1$ years). mRNA expression of pro-apoptotic (BAX, CASP3, CASP8) and anti-apoptotic (BCL2, AMH, AMHR, FSHR, LHR, CYP19A1) factors was determined by quantitative RT-PCR using ROCHE LightCycler 480.

Results

No significant difference in GC or FF mRNA expression of pro- and anti-apoptotic factors could be demonstrated between IVF patients with (9 patients) or without (22 patients) clinical pregnancy. Each transcript investigated was detected in FF, but their levels were markedly reduced and independent of those in GCs. The number of retrieved oocytes was positively associated with GC AMHR ( $r=0.393, p=0.029)$, but the day of embryo transfer was negatively associated with GC LHR $(r=-0.414, p=0.020)$ and GC FSHR transcripts $(r=-0.535, p=0.002)$. When pregnancy positive group was analysed separately the impact of apoptosis- related gene expressions on some selected measures of IVF success could be observed. Strong positive relationship was found between gene expression levels of pro- and anti-apoptotic factors in GCs.

\section{Conclusion}

Our study provides only marginal evidences for the apoptosis dependence of IVF outcome and suggests that the apoptosis process induces adaptive increases of the anti-apoptotic gene expression to attenuate apoptosis and to protect cell survival.

\section{Background}

Convincing evidence have been provided for the prominent role of apoptosis in female reproduction [1, 2, 3]. Apoptosis of ovarian cells is intimately involved in the regulation of folliculogenesis, gametogenesis, fertilization and embryonic development. It is a physiological process provided that the pro-apoptotic factors are in balance with factors promoting cell survival. When pro-apoptotic factors predominate over anti-apoptotic ones the finely tuned complex interaction between the two opposing systems is disturbed, apoptosis accelerates, the ovarium reserve declines, and early ovarium aging occurs. As a result, the female fertilization potential is compromised $[4,5,6,7,8,9,10]$. Based on these observations the apoptosis-related elements have been widely investigated and they have been claimed to be reliable markers to predict in vitro fertilization (IVF) outcome [11].

These observations have revealed that in mammalian ovaries the apoptosis of granulosa cells (GCs) and oocytes has deleterious effects on oocyte maturation, fertilization and embryonic development in vitro and in vivo. Apoptotic cell death is characterized morphologically by cytoplasmic and chromatin condensation, membrane blebbing, fragmentation of cells into membrane-bound apoptotic bodies and phagocytosis by the neighbouring cells. Biochemically two major death pathways have been identified that are involved in the initiation of ovarian apoptosis: a/ the transmembrane death receptor Fas and its ligand- FasL system when activated induces the release of pro-apoptotic proteins (procaspase-8 and procaspase-3) [12] and b/ mitochondrial and endoplasmatic reticulum-associated pathways. In the former cytochrome $\mathrm{c}$ release interferes with electron transport, cellular redox status and liberates caspase (CASP) activator proteins [13]. In the latter endoplasmic reticulum stress induces apoptosis via the function of CASP12 [14].

The current view that apoptosis of GCs can be used to characterize the competence of oocytes and pre-implantation embryos, however, has been recently challenged $[8,15]$. In a most recent review by Regan et al it is written "apoptosis levels of the GCs are reflective of the proliferative stage of the follicle rather than a predictor of oocyte health". Accordingly, its predictive value for oocyte quality and ensuring pregnancy rate is poor [8].

With respect to these apparent controversies the present study was designed to measure the expression profile of apoptosis-related genes in patients undergoing IVF. Specifically, we determined the mRNA expression of pro-apoptotic factors CASP3, CASP8 and BCL2 associated X apoptosis regulator (BAX), as well as that of anti-apoptotic factors BCL2 apoptosis regulator, FSH receptor (FSHR), LH receptor (LHR), anti-Müllerian hormone (AMH), anti-Müllerian hormone receptor type 2 (AMHR 2) and cytochrome P450 family 19 subfamily A member 1 (CYP19A1) in GCs and cell-free follicular fluid (FF) obtained during oocyte retrieval. Attempt was also made to relate these genes to the outcome measures of IVF (number of mature oocytes, viable embryos and pregnancy rate).

\section{Material And Methods}

\section{Patients}

This observational, clinical study was carried out between 1 September 2019 and 1 December 2019 in the Assisted Reproduction Unit, Department of Obstetrics and Gynecology, University of Pécs, Pécs, Hungary. The study comprised 31 consecutive patients who were indicated for fertility treatment. Eligible patients were recruited according to the data of fertility consultation. They did not have metabolic or vascular diseases (obesity, diabetes mellitus, metabolic syndrome, fatty liver diseases and atherosclerosis) or renal diseases. Enrolment of patients into the IVF procedure was approved by two independent 
physicians. Superovulation treatment, fertilization methods and embryo selection were performed according to standard protocols as described in our previous publication [16]. The major clinical and laboratory characteristics of the patients are summarized in Table I.

\section{Sample collection and preparations}

FF and GCs were obtained by follicle puncture at oocyte retrieval. The collected FF was centrifuged for 10 minutes at $252 \times \mathrm{g}$ and the untreated supernatants were frozen and stored at $-80^{\circ} \mathrm{C}$ until analysis. For GCs FF sediments were incubated in G-IVF ${ }^{\mathrm{TM}}$ solution for two hours. The mixture was subjected to mechanical and enzymatic treatment in G-Mops ${ }^{\mathrm{TM}}$ solution to cleanse the oocytes. At the end of this procedure the sediment contained GC concentrate. $0.5 \mathrm{ml}$ of this concentrate was injected into DNA/RNA LoBind Tube and $1 \mathrm{ml}$ ExtraZol Tri-reagent (EM30-200 NucleotestBio Budapest, Hungary) was added. This mixture was incubated in room temperature for 10 minutes, then stored at- $80^{\circ} \mathrm{C}$ for future analysis.

\section{Total RNA isolation and Q-RT-PCR}

$100 \mu \mathrm{l}$ of follicle fluid/400 $\mu \mathrm{l}$ of GC suspension was used for RNA isolation. Total cellular RNA was isolated using the ExtraZol Tri-reagent (EM30-200 NucleotestBio Budapest, Hungary) according to the manufacturer's standard procedures. The primary sequences of the internal control (housekeeping gene) hypoxanthine phosphoribosyltransferase 1 (HPRT 1) were designed with Primer Express ${ }^{\text {TM }}$ Software (Applied Biosystemes, Budapest, Hungary) and synthesized by Integrated DNA Technologies (Bio-Sciences, Budapest, Hungary). The primer sequences are shown in Table 2.

The analysis of gene expression was performed by quantitative RT-PCR using a Roche LightCycler 480 Instrument I (Roche Molecular Systems, Inc. Budapest, Hungary). The thermo-program has been set by the KAPA SYBR® FAST One-Step kit (KK4681, Merck, Hungary) protocol.

The resulting reaction mixture was measured: $10 \mu \mathrm{l} /$ cell KAPA SYBR FASTqPRC Master Mix, $0.4 \mu \mathrm{l} /$ cell KAPA RT Mix, $0.4 \mu \mathrm{l} /$ cell dUTP, $0.4 \mu \mathrm{l} /$ cell primers, sterile bidest water, $5 \mu \mathrm{l} /$ cell template mRNA.

The PCR thermocycling conditions were as follows: Reverse transcription step at $42^{\circ} \mathrm{C}$ for 5 min follows the enzyme activation $95^{\circ} \mathrm{C}$ for 3 sec. The PCR reactions were carried out for 40 cycles that comprised a denaturation step at $95^{\circ} \mathrm{C}$ for $10 \mathrm{sec}$, an annealing step at $58^{\circ} \mathrm{C}$ for 20 sec and an extension step at $72^{\circ} \mathrm{C}$ for $5 \mathrm{sec}$. The results were analysed by the relative quantification $\left(\Delta \Delta_{\mathrm{CT}}\right)$ method [17].

\section{Statistical analysis}

Statistical analysis was performed using IBM SPSS 24.0 software (IBM Corp., Armonk, NY, USA). Normality of data distribution was tested by the Kolmogorov-Smirnov test. To compare continuous variables Mann-Whitney U-test or Wilcoxon W-test were used. The association between two continuous variables was tested by using Spearman's or Pearson's correlation coefficients. The data are expressed as mean \pm SD and $p<0.05$ was considered statistically significant.

\section{Results}

The mRNA expression of anti-apoptotic (BCL2, LHR, FSHR, AMH, AMHR2, CYP19A1) and pro-apoptotic (CASP3, CASP8, BAX) factors in GCs and FF of the whole patient population is shown in Fig. 1. It can be seen that each transcript studied is present in both GCs and FF, but except for BCL2, their FF levels are markedly reduced when compared to those in GCs.

To assess the possible contribution of mRNA expressions measured in GC to their respective levels in FF we analysed the relationship between the corresponding parameters of GC and FF. As we could not demonstrate significant association between transcripts obtained simultaneously from GC and FF our results can be regarded as indicating that these transcripts may originate from several follicular cells including the GC.

Our results were also evaluated according to the IVF outcome (Table 3). Patients with clinical pregnancy (9 patients) were compared with those who failed to become clinically pregnant (22 patients) and we could not detect significant differences between the groups either in GS or in FF expression of pro-or antiapoptotic factors. However, anti-apoptotic AMH, AMHR2, LHR and FSHR in GC tended to be higher in the pregnant than in the non-pregnant group.

No consistent changes were associated with pregnancy in any other apoptosis-related gene expression investigated either in GC or in FF.

The interrelationship between mRNA expression of pro- and anti-apoptotic factors was also analysed. Interestingly, significant positive relationship was found of GC BAX to GC AMH, AMRH2, LHR and to FSHR. GC CASP3 was also related to AMHR2, to LHR and to FSHR. Similar associations were observed between GC CASP8 and AMHR2, LHR and ESHR (Table 4). These associations apply to the whole IVF population and to the patients of the pregnant group but not to those who did not conceive and progress to clinical pregnancy. Based on these results it is reasonable to assume that apoptotic process initiates increase of gene expression of anti-apoptotic factors to protect cell survival.

To get more insight into the clinical relevance of apoptosis in IVF treated patients selected clinical and laboratory variables including parameters of IVF outcome were investigated as a function of apoptosis markers. It was demonstrated that in the whole IVF population maternal age, BMI, FSH dosage for stimulation, number of mature oocytes and hCG levels on day 12 proved to be independent of apoptosis markers. However, the number of retrieved oocytes, was positively related to GC AMHR2 gene expression $(r=0.393, p=0.029)$, whereas the day of embryo transfer was negatively related to the mRNA expression of GC LHR $(r=-0.414, p=0.020)$ and FSHR $(r=-0.535, p=0.002)$. When only patients of the pregnant group were considered significant negative association was found of GC BAX transcript to the number of IVF cycles $(r=-0.694, p=0.038)$ and FF transcripts of CASP3 to number of retrieved $(r=-0.841, p=0.036)$ and mature oocytes $(r=-0.833, p=0.020)$. Furthermore, the number of transferred embryos was negatively affected by mRNA expression of $F F$ BAX ( $r=-0.920, p=$ $0.008)$ and FF CASP8 $(r=-0.926, p=0.008)$. 
Out of anti-apoptotic factors only GC FSHR and AMHR2 transcripts influenced negatively the day of embryos transfer ( $r=-0.860, p=0.003)$ and the number of transferred embryos $(r=-0.926, p=0.008)$, respectively.

\section{Discussion}

The present study demonstrated no significant differences in GS or FF mRNA expression of pro-and anti-apoptotic factors between IVF patients with or without clinical pregnancy. Each pro-apoptotic (BAX, CASP3, CASP8) and anti-apoptotic (BCL2, AMH, AMHR2, CYP19A1, LHR, FSHR) transcripts investigated could be detected in FF, but their levels were markedly reduced and proved to be independent of those in CG. Furthermore, some selected measures of IVF success (number of retrieved and mature oocytes, the day and number of embryo transfer and the number of IVF cycles) were associated with one or more apoptosis-related gene expression. The study, therefore, provided only marginal evidence for the apoptosis dependence of IVF outcome. Importantly, highly significant positive correlations were seen between mRNA expression of pro- and anti-apoptotic factors giving rise to the possibility that the apoptotic process induced adaptive increases of the anti-apoptotic gene expression to attenuate apoptosis and to protect cell survival.

The concept that reduction in apoptotic granulosa-lutein cells in women undergoing IVF treatment is associated with better outcome appears to be wellestablished. In support of this notion Oosterhuis et al using flow-cytometry reported $7.1 \pm 5.1 \%$ apoptotic cells in pregnant as compared to the $20.7 \pm 13.7 \%$ in non-pregnant patients [1]. Similarly, Nakahara et al have shown that apoptotic GCs cells estimated by fluorescence microscopy were lower when women conceived, and ongoing pregnancy was achieved [2]. The study by Seifer et al has also indicated that apoptosis is a measure of ovarian reserve and reflects reproductive potential [18]. Furthermore, evidence has been provided that apoptosis can be associated with poor embryo quality [19]. Comparison of GC apoptosis and clinical outcome of IVF patients with normal and diminished ovarian reserve has also revealed that higher rate of CG apoptosis resulted in a significant reduction in the number of retrieved oocytes and good quality embryos [10]. Consistent with these observations induction of apoptosis of human GCs obtained from IVF patients with interferon gamma and an anti-human Fas antibody showed that low percentage of apoptotic GCs (11.6 $\pm 4.8 \%$ vs $59.5 \pm$ $14.8 \%$ ) yielded significantly higher pregnancy rate, consequently GC apoptosis might serve as a marker of IVF outcome [20].

In spite of accumulating evidence for the involvement of apoptosis in reproduction its major role in regulating ovarium reserve and IVF outcome has been questioned. Accordingly, GC apoptosis is regarded to be a physiological process to eliminate unwanted cells during the period of folliculogenesis, oogenesis and embryogenesis. In support of this view no significant differences were observed in the percentage of apoptotic GCs and apoptotic cumulus cells between follicles with or without fertilized oocytes [14, 21, 22]. Furthermore, in a series of recent reports by Regan et al it has been found that the aging- related reduced expression and dysregulation of GC receptors for anti-apoptotic FSHR, LHR and BMPA (bone morphogenetic protein) were associated with lower levels of apoptotic GCs than those in younger women $[15,23,24]$.

To reconcile these apparent controversies the contribution of patients' selection bias, different methodologies and developmental stages, as well as posttranslational modifications in the signalling pathways are to be considered. Our present study may shed light to an unexplored possibility. The apoptotic process induces an adaptive increase of the expression of anti-apoptotic genes (AMH, AMHR, FSHR, LHR) that counterbalance the effects of pro-apoptotic factors, re-establish the equilibrium between the mRNA abundance for cell death and survival thus promoting IVF success.

The presence of apoptosis-related mRNAs in FF needs to be commented on. It was assumed that these transcripts are released from CGs, reflect apoptotic state of GCs and can be used as biomarkers of oocyte maturation, embryo development and pregnancy rate in IVF patients. However, we failed to document such associations suggesting that they derive not only from GCs but also from other follicular cells. Furthermore, except for FF AMH and AMHR, mRNAs in FF have no consistent impact on IVF success. Importantly, cell-free DNA [25, 26] and soluble Fas levels in FF [27] correlated positively with GC apoptosis and negatively with embryo quality and pregnancy rate.

\section{Conclusions}

Taken together, in the light of our present observations we are reluctant to claim decisive role

for apoptosis in impaired ovarian function and reproductive potential, but rather we line up with

those who challenge its major contribution.

\section{Study Limitations}

Relatively small number of patients with heterogeneous infertility diagnosis was included in this study. Moreover, apoptotic GCs were not identified and counted, and the possible post-translational modifications of the gene products were not considered. Further large-scale studies are to be conducted to overcome these practical and theoretical bias.

\section{Abbreviations}

$\mathrm{AMH}$ - anti-Müllerian hormone

AMHR2 - anti-Müllerian hormone receptor 2

BAX - BCL2 associated $X$ apoptosis regulator

BCL2 - apoptosis regulator 
BMI - Body Mass Index

CASP3 - caspase 3

CASP8 - caspase 8

CYP19A1 - cytochrome P450 family 19 subfamily A member 1

FF - follicular fluid

FSH - Follicle-stimulating hormone

FSHR - follicle stimulating hormone receptor

GCs - granulosa cells

hCG - Human chorionic gonadotropin

HPRT1 - hypoxanthine phosphoribosyl transferase 1 (housekeeping gene)

IVF - in vitro fertilization

LHR - luteinizing hormone receptor

Q-RT-PCR - Real-Time Quantitative Reverse Transcription Polymerase Chain Reaction

\section{Declarations}

Ethics approval and consent to participate

The study was reviewed and approval by the Human Reproduction Committee of the Hungarian Medical Research Council (5273-2/2012 HER). The investigation conforms to the principles outlined in the Declaration of Helsinki. Signed informed consent was obtained from all patients who participated in the study.

\section{Consent for publication}

Not applicable

Availability of data and material

The dataset supporting the conclusions of this article is available from the corresponding author on reasonable request.

Competing interests

The authors state that there are no conflicts of interest regarding the publication of this article.

\section{Funding}

This work was supported by the National Laboratory on Reproduction as part of the "Establishment of National Laboratories 2020" program and by GINOP2.3.2-15-2016-00021 ("The use of chip-technology in increasing the effectiveness of human in vitro fertilization"). The funding sources did not have any role in the study design; in collection, analysis and interpretation of data, or in writing and submitting this manuscript.

\section{Authors' contributions}

All authors read and approved the final manuscript. JB, ES and MK conceived, designed and managed the study, JB, ES and AV contributed to the study conceptualization and provided critical editorial input to the interpretation of the data, TV, ASZ, KG and AM contributed in laboratory and statistical analysis, ÁV, ES and VP contributed to data collection, to the drafting and final editing of the manuscript.

Acknowledgement

The authors are grateful to the IVF patients for their participation in this study.

\section{References}

1. Oosterhuis GJ, Michgelsen HW, Lambalk CB, Schoemaker J, Vermes I. Apoptotic cell death in human granulosa-lutein cell: a possible indicator of in vitro fertilization outcome. Fertril Steril. 1998;70:474-9.

2. Nakahara K, Knight PG, Saito T, Ito M, Ohta N, Sakai N, et al. Incidence of apoptotic bodies in membrane granulosa of the patients participating in an in vitro fertilization program. Fertil Steril. 1997;67:302-8. 
3. Jiang J-Y, Cheung CKM, Wang Y, Tsang BK. Relationship of cell death and cell survival gene expression during ovarian follicular development and atresia. Front Biosci. 2003;8:222-37.

4. Tal R, Seifer DB. Ovarian reserve testing: a user's guide. Am J Obstet Gynecol. 2017;217:129-40.

5. Levi AJ, Rajnault MF, Bergh PA, Drews MR, Miller BT, Scott RT Jr. Reproductive outcome in patients with diminished ovarian reserve. Fertil Steril. 2001;76:666-9.

6. Almeida CP, Ferreira MCF, Silveira CO, Campos JR, Borges IT, Bacta PG, et al. Clinical correlation of apoptosis in human granulosa cell - a review. Cell Biol Int. 2018;42:1276-81.

7. Lee KS, Joo BS, Na YJ, Yoon MS, Choi OH, Kim WW. Cumulus cells apoptosis as an indicator to predict the quality of oocytes and the outcome of IVF-ET. J Assist Reprod Genet. 2001;18:490-8.

8. Regan SLP, Knight PG, Yovich JL, Stanger JD, Leung Y, Arfuso F, et al. The effect of ovarian reserve and receptor signalling on granulosa cell apoptosis during human follicle development. Mol Cell Endocrinol. 2018;470:219-27.

9. Gurtcheff SE, Klein NA. Diminished ovarian reserve and infertility. Clin Obstet Gynecol. 2011;54:666-74.

10. Fan Y, Chang Y, Wei L, Chen J, Li J, Goldsmith S, Silber S, Liang X. Apoptosis of mural granulosa cells is increased in women with diminished ovarian reserve. J Assist Reprod Genet. 2019;36:1225-35.

11. Haouzi D, Hasmamah S. Pertinence of apoptotic markers for the improvement of in vitro fertilization (IVF). Curr Med Chem. 2009;16:1905-16.

12. Chinniyan AM, O'Rourke K, Tewari M, Dixit VM. FADD, a novel death domain-containing protein, interacts with the death domain of Fas and apoptosis. Cell. 1995;81:505-12.

13. Green DR, Reed JC. Mitochondria and apoptosis. Science. 1998;281:1309-12.

14. Nagakawa T, Zhu H, Morishima N, Li E, Xu J, Yanker BA, Yuan J. Caspase 12 mediates endoplasmic-reticulum-specific apoptosis and cytotoxicity by amyloid-beta. Nature. 2000;403:98-103.

15. Jancar N, Kopitar AN, Ihan A, Klun IV, Bokal EV. Effect of apoptosis and reactive oxygen species production in human granulosa cells on oocyte fertilization and blastocyst development. J Assist Reprod Genet. 2007;24:91-7.

16. Várnagy A, Bódis J, Kovács GL, Sulyok E, Rauh M, Rascher W. Metabolic hormones in follicular fluid in women undergoing in vitro fertilization. J Reprod Med. 2013;58:305-11.

17. Livak KJ, Schmittgen TD. Analysis of relative gene expression data using real-time quantitative PCR and the 2(Delta Delta C(T)) Method. Methods. 2001;25:402-8.

18. Seifer DB, Gardiner AC, Ferreir AKA, Peluso JJ. Apoptsosis as a function of ovarian reserve in women undergoing in vitro fertilization. Fertil Steril. 1996;66:593-8.

19. Hardy K. Apoptosis in the human embryo. Rev Reprod. 1999;4:125-34.

20. Sifer C, Bénifla J-L, Brainguier A-F, Porcher R, Blanc-Layrac G, Madélénat P, Feldmann G. Could induced apoptosis of human granulosa cells predict in vitro fertilization-embryotransfer outcome? A preliminary study of 25 women. Eur J Obstet Gynecol Reprod Biol. 2002;103:150-3.

21. Clavero A, Castilla JA, Nanez Al, Garcia-Pena M, Maldonado V, Fontes J, Mendoza N, Maratinez L. Apoptosis in human granulosa cells after induction of ovulation in women participating in an intracytoplasmic sperm injection program. Eur J Obstet Gynecol Reprod Biol. 2003;110:181-5.

22. Corn CM, Hauser-Kronberger C, Moser M, Tews G, Ebner T. Predictive value of cumulus cell apoptosis with regard to blastocyst development of corresponding gametes. Ferti Steril. 2005;84,627 - 33.

23. Regan SLP, Knight PG, Yovich JL, Stanger JD, Leung Y, Arfuso F, et al. The effect of ovarian reserve on receptor signalling and granulosa cell apoptosis during human follicle development. Mol Cell Endocrinol. 2017;470:219-27.

24. Regan SLP, Knight PG, Yovich JL, Stanger JD, Leung Y, Arsfuso F. el al. Infertility and ovarian follicle reserve depletion are associated with the dysregulation of the FSH and LH receptor density in human antral follicle. Mol Cell Endocrinol. 2017;446:40-51.

25. Salici E, Travers S, Molinary N, et al. Cell-free DNA in human follicular fluid as biomarker of embryo quality. Human Reprod. 2014;29:2661-9.

26. Guan Y, Hang W, Wang X, Cai P, Jia Q, Zhao W. Cell-free DNA induced apoptosis of granulosa cells by oxidative stress. Clin Chim Acta. $2017 ; 473: 213-7$.

27. Malamitsi-Puchner A, Sarandakou A, Baka S, Wrachnis N, Kouskouni E, Hassiakos D. Soluble Fas concentrations in the follicular fluid and oocyte-cumulus complex culture medium from women undergoing in vitro fertilization: association with oocyte maturity, fertilization and embryo quality. J Soc Gynecol Invest. 2004;11:566-9.

\section{Tables}

Table 1

The major clinical and laboratory characteristics of IVF patients who progressed to chemical/clinical pregnancy and those who failed to become pregnant. $($ mean $\pm S D)$ 


\begin{tabular}{|c|c|c|c|c|}
\hline & All patients & Pregnancy- negative group & Pregnancy- positive group & Intergroup difference* \\
\hline & $(n=31)$ & $(n=20)$ & $(n=11)$ & $\mathrm{p}$ \\
\hline Age (years) & $34.35 \pm 5.84$ & $35.45 \pm 6.21$ & $31.67 \pm 3.91$ & 0.030 \\
\hline $\mathrm{BMI}\left(\mathrm{kg} / \mathrm{m}^{2}\right)$ & $24.02 \pm 3.12$ & $24.06 \pm 3.29$ & $23.92 \pm 2.85$ & 0.273 \\
\hline $\begin{array}{l}\text { Female infertility, } \\
\mathrm{n}(\%)\end{array}$ & $14(45.16)$ & $9(45.00)$ & $5(45.45)$ & 0.981 \\
\hline $\begin{array}{l}\text { Male infertility, } \\
\mathrm{n}(\%)\end{array}$ & $17(54.84)$ & $11(55.00)$ & $6(54.55)$ & \\
\hline Number of previous IVF, $\mathrm{n}$ & $2.10 \pm 1.45$ & $2.18 \pm 1.53$ & $1.89 \pm 1.27$ & 0.660 \\
\hline Serum oestradiol (pmol/l) & $2919.83 \pm 3379.44$ & $3394.86 \pm 3916.90$ & $1811.44 \pm 1034.49$ & 0.930 \\
\hline Serum progesterone (pmol/l) & $39.58 \pm 21.83$ & $39.90 \pm 24.51$ & $38.74 \pm 13.71$ & 0.854 \\
\hline $\begin{array}{l}\text { Serum } \\
\text { LH (IU) }\end{array}$ & $5.02 \pm 5.07$ & $5.11 \pm 5.89$ & $4.83 \pm 2.78$ & 0.291 \\
\hline Dose of FSH stimulation (IU) & $1716.13 \pm 775.20$ & $1790.91 \pm 842.10$ & $1533.33 \pm 582.29$ & 0.836 \\
\hline Retrieved oocytes (n) & $8.16 \pm 4.87$ & $7.23 \pm 4.86$ & $10.44 \pm 4.30$ & 0.164 \\
\hline Duration of stimulation days & $4.03 \pm 1.92$ & $3.55 \pm 1.50$ & $5.22 \pm 2.39$ & 0.266 \\
\hline Matured oocytes (n) & $6.94 \pm 4.59$ & $6.00 \pm 4.51$ & $9.22 \pm 4.15$ & 0.406 \\
\hline Viable (Grade I) embryo (n) & $4.03 \pm 3.41$ & $3.50 \pm 3.41$ & $5.33 \pm 3.24$ & 0.373 \\
\hline Transferred embryo (n) & $1.71 \pm 1.35$ & $1.73 \pm 1.55$ & $1.67 \pm 0.71$ & 0.768 \\
\hline Serum hCG on day 12 (IU) & $209.33 \pm 442.26$ & $22.97 \pm 80.52$ & $664.87 \pm 622.48$ & 0.000 \\
\hline Chemical pregnancy $\mathrm{n}(\%)$ & & & $11(35.5)$ & \\
\hline Clinical pregnancy n (\%) & & & $9(29.0)$ & \\
\hline
\end{tabular}

Table 2

Sequence of primers used for Q-RT-PCR analysis 


\begin{tabular}{|c|c|c|}
\hline Gene name & forward primer sequences $\left(5^{\prime}-3^{\prime}\right)$ & reverse primer sequence $\left(5^{\prime}-3^{\prime}\right)$ \\
\hline BCL2 & GGCCAGGGTCAGAGTTA & СCTCTCTTGCGGAGTATTTG \\
\hline LHR & GAGATGCACTGTCCAATCC & CCGAATCGAGAGCTGTAATG \\
\hline FSHR & GGAAGAATCAGGTGGATGG & GGGAGGTCAGAAGGAATCT \\
\hline $\mathrm{AMH}$ & CTTCCTGGAGACGCTCA & GGTCCGACAGGTTGACTA \\
\hline AMHR2 & GGGCTTTGGGCATTACTT & TGTAGAGGCAGCGGATAG \\
\hline CYP19A1 & CAGTGCCTGCAACTACTAC & CCCGAATCGAGAGCTGTAATG \\
\hline CASP3 & CTGAGCCATGGTGAAGAAG & CGGCAGGCCTGAATAATG \\
\hline CASP8 & CCAGTGGGCAAGAGAATTAG & CAAGTGACCAACTCAAGGG \\
\hline BAX & GAGCTGCAGAGGATGATTG & GCCTTGAGCACCAGTTT \\
\hline HPRT1 & TGCTTCTCCTCAGCTTCA & CTCAGGAGGAGGADGCC \\
\hline \multicolumn{3}{|c|}{ Abbreviations: } \\
\hline \multicolumn{3}{|c|}{ BCL2 = BCL2 apoptosis regulator } \\
\hline \multicolumn{3}{|c|}{ LHR = luteinizing hormone receptor } \\
\hline \multicolumn{3}{|c|}{ FSHR = follicle stimulating hormone receptor } \\
\hline \multicolumn{3}{|c|}{ AMH = anti-Müllerian hormone } \\
\hline \multicolumn{3}{|c|}{ AMHR2 = anti-Müllerian hormone receptor 2} \\
\hline \multicolumn{3}{|c|}{ CYP19A1 = cytochrome P450 family 19 subfamily A member 1} \\
\hline \multicolumn{3}{|c|}{ CASP3 $=$ caspase 3} \\
\hline \multicolumn{3}{|c|}{ CASP8 $=$ caspase 8} \\
\hline \multicolumn{3}{|c|}{$\mathrm{BAX}=\mathrm{BCL} 2$ associated $\mathrm{X}$ apoptosis regulator } \\
\hline HPRT1 = hyp & xanthine phosphoribosyl transfera & e 1 (housekeeping gene) \\
\hline
\end{tabular}

Table 3

Comparison of gene expression of anti- and pro-apoptotic factors in Pregnancy-positive and Pregnancy-negative IVF patients (mean \pm SD)

\begin{tabular}{|c|c|c|c|c|c|c|c|c|c|c|c|c|c|c|c|}
\hline & & BCL2 & & LHR & & FSHR & & AMH & & HR & & 19A1 & BA & & $C A$ \\
\hline & & GS & $\mathrm{FF}$ & GS & $\mathrm{FF}$ & GS & $\mathrm{FF}$ & GS & $\mathrm{FF}$ & GS & FF & GS & FF & GS & $\mathrm{FF}$ \\
\hline \multirow{2}{*}{$\begin{array}{l}\text { Pregnancy- } \\
\text { positive }\end{array}$} & Mean & 0.033 & 0.008 & 0.113 & 0.015 & 0.113 & 0.033 & 0.032 & 0.018 & 0.147 & 0.023 & 0.165 & 0.566 & 0.057 & 0.036 \\
\hline & $S D$ & 0.073 & 0.010 & 0.146 & 0.008 & 0.114 & 0.019 & 0.030 & 0.016 & 0.078 & 0.019 & 0.169 & 0.869 & 0.041 & 0.029 \\
\hline \multirow{4}{*}{$\begin{array}{l}\text { Pregnancy- } \\
\text { negative }\end{array}$} & Mean & 0.023 & 0.009 & 0.191 & 0.021 & 0.149 & 0.037 & 0.032 & 0.023 & 0.093 & 0.028 & 1.806 & 0.278 & 0.047 & 0.027 \\
\hline & $S D$ & 0.052 & 0.014 & 0.363 & 0.012 & 0.276 & 0.030 & 0.027 & 0.026 & 0.109 & 0.021 & 5.560 & 0.256 & 0.044 & 0.021 \\
\hline & Z & -1.219 & -0.221 & -0.131 & -0.922 & -0.261 & -0.221 & -0.152 & 0.000 & -1.915 & -0.516 & -1.480 & -0.590 & -0.696 & -1.012 \\
\hline & $\mathrm{p}$ & 0.223 & 0.825 & 0.896 & 0.357 & 0.794 & 0.825 & 0.879 & 1.000 & 0.056 & 0.606 & 0.139 & 0.555 & 0.486 & 0.312 \\
\hline
\end{tabular}

Abbreviations as in Table 2

$\mathrm{GS}=$ granulosa cell

$\mathrm{FF}=$ follicular fluid

Table 4

Interrelationship of the mRNA expression of pro- and anti-apoptotic factors in granulosa cell 


\begin{tabular}{|c|c|c|c|c|c|c|c|}
\hline & & AMH & AMHR2 & CYP19A1 & LHR & FSHR & BCL2 \\
\hline \multicolumn{8}{|c|}{ All patients $(n=31)$} \\
\hline \multirow[t]{2}{*}{ BAX } & $\mathrm{R}$ & $0.360^{*}$ & $0.537^{\star \star}$ & -0.062 & $0.620^{\star *}$ & $0.398^{*}$ & $0.672^{\star \star}$ \\
\hline & $\mathrm{p}$ & 0.046 & 0.002 & 0.742 & 0.000 & 0.027 & 0.000 \\
\hline \multirow[t]{2}{*}{ CASP3 } & $\mathrm{R}$ & 0.303 & $0.509^{\star *}$ & $-0.364^{\star}$ & $0.692^{\star \star}$ & $0.555^{\star \star}$ & $0.693^{\star \star}$ \\
\hline & $\mathrm{p}$ & 0.097 & 0.003 & 0.044 & 0.000 & 0.001 & 0.000 \\
\hline \multirow[t]{2}{*}{ CASP8 } & $\mathrm{R}$ & 0.301 & $0.585^{\star *}$ & -0.316 & $0.655^{\star \star}$ & $0.551^{\star \star}$ & $0.668^{* \star}$ \\
\hline & $\mathrm{p}$ & 0.099 & 0.001 & 0.083 & 0.000 & 0.001 & 0.000 \\
\hline \multicolumn{8}{|c|}{ Pregnancy-positive $(n=9)$} \\
\hline \multirow[t]{2}{*}{ BAX } & $\mathrm{R}$ & .373 & $.553^{\star *}$ & .051 & $.570^{\star *}$ & $.529^{\star}$ & $.670^{\star *}$ \\
\hline & $\mathrm{p}$ & .087 & .008 & .822 & .006 & .011 & .001 \\
\hline \multirow[t]{2}{*}{ CASP3 } & $\mathrm{R}$ & .224 & $.493^{*}$ & -.227 & $.709^{\star *}$ & $.654^{\star \star}$ & $.715^{\star *}$ \\
\hline & $\mathrm{p}$ & .317 & .020 & .311 & .000 & .001 & .000 \\
\hline \multirow[t]{2}{*}{ CASP8 } & $\mathrm{R}$ & .146 & $.789^{\star *}$ & -.226 & $.828^{\star *}$ & $.773^{\star *}$ & $.805^{\star *}$ \\
\hline & $\mathrm{p}$ & .516 & .000 & .312 & .000 & .000 & .000 \\
\hline \multicolumn{8}{|c|}{ Abbreviations as in Table 2} \\
\hline \multicolumn{8}{|c|}{${ }^{*} p \leq 0.005$} \\
\hline \multicolumn{8}{|c|}{${ }^{\star *} p \leq 0.001$} \\
\hline
\end{tabular}

\section{Figures}


3,500

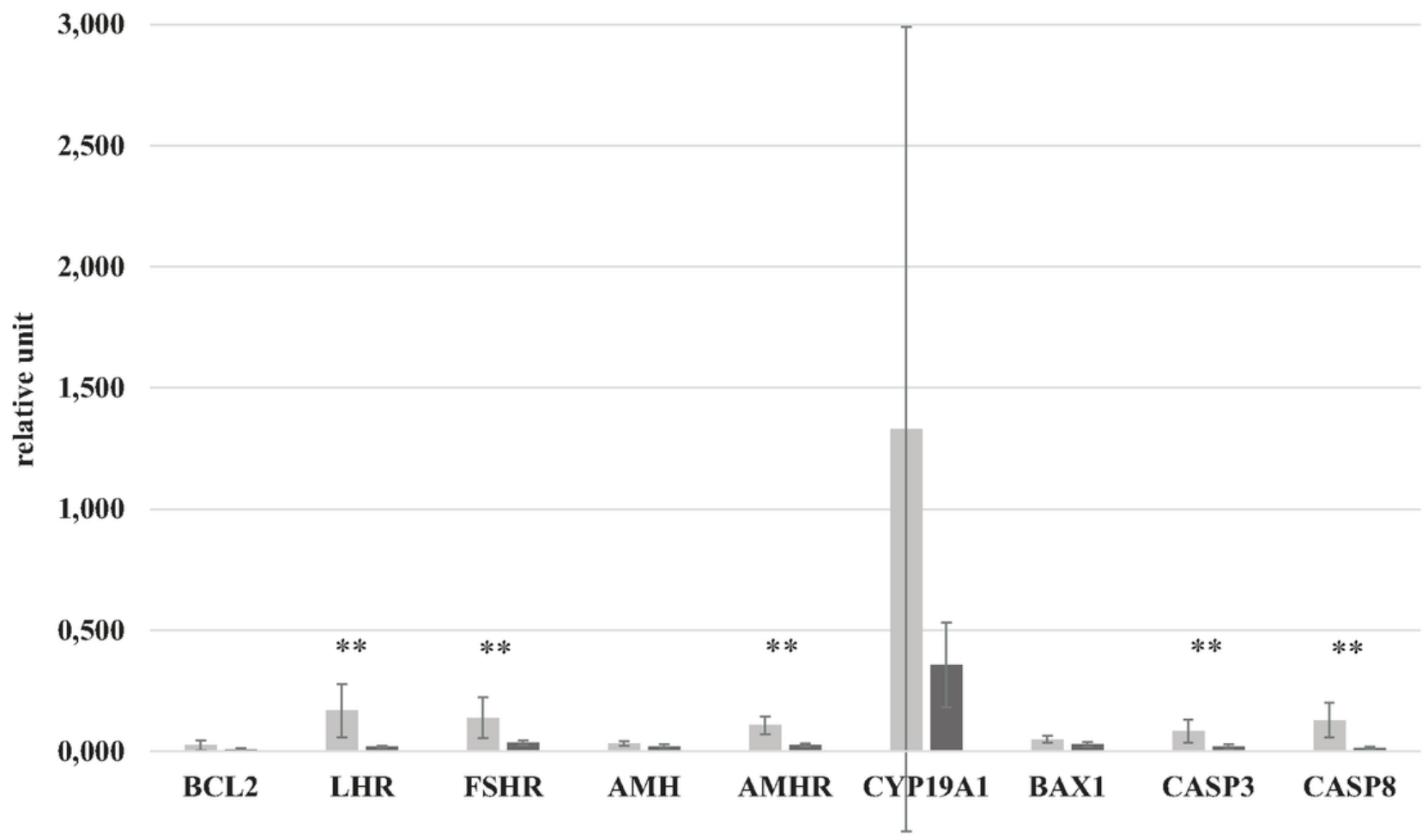

$-0,500$

granulosa cell $\square$ follicular fluid

Figure 1

Gene expression levels of anti- and pro-apoptotic factors in granulosa cells and follicular fluid in IVF patients $(n=31, m e a n \pm S D) * \star p \leq 0.001$ Abbreviations as in Table 2 